\title{
Brönsted acid surfactant-combined dicationic ionic liquids as green catalysts for biodiesel synthesis from free fatty acids and alcohols
}

\author{
Tao Chang a, Leqin He a,b, Xiaojing Zhang a, Mingxia Yuan a, Shenjun Qin ${ }^{\text {a,* }}$, Jiquan Zhao b,\# \\ a Key Laboratory for Resource Exploration Research of Hebei Province, Hebei University of Engineering, Handan 056038, Hebei, China; \\ b School of Chemical Engineering, Hebei University of Technology, Tianjin 300130, China
}

A R T I C L E I N F O

Article history:

Received 29 January 2015

Accepted 27 March 2015

Published 20 July 2015

\section{Keywords:}

Biodiesel

Esterification

Brönsted acidity

Surfactant-combined dicationic ionic

liquid

Phase separated catalyst

\begin{abstract}
A B S T R A C T
Quaternary ammonium Brönsted acid surfactant-combined dicationic ionic liquids (BASDILs) based on zwitterionic 1,2-bis[ $N$-methyl- $N$-(3-sulfopropyl)-alkylammonium]ethane betaines and various anions were prepared and characterized. BASDILs possess properties similar to those of phase-separated catalysts and were applied to the catalytic synthesis of biodiesel from free fatty acids and alcohols. Several factors were investigated and the results indicated that $\left[\mathrm{C}_{12} \mathrm{Sb}\right]\left[p-\mathrm{CH}_{3} \mathrm{C}_{6} \mathrm{H}_{4} \mathrm{SO}_{3}\right]$ was the optimal catalyst, with good catalytic performance and reusability under mild conditions.
\end{abstract}

(C) 2015, Dalian Institute of Chemical Physics, Chinese Academy of Sciences. Published by Elsevier B.V. All rights reserved.

\section{Introduction}

Because of environmental concerns and the ongoing depletion of fossil fuels, biodiesel has attracted considerable attention during the past decade as an alternative, green and renewable fuel [1]. Biodiesel is generally produced from vegetable oils or animal fats by transesterification of triglycerides [2-4] or by esterification of free fatty acids (FFAs) with short-chain aliphatic alcohols [5-9]. However, the mineral acids that are employed for this purpose in industrial processes cannot be recycled and have other disadvantages [10]. In addition, the rate of the esterification reaction with heterogeneous catalysts is adversely affected by mass transfer limitations resulting from the heterogeneous reaction conditions [11]. Hence, it would be beneficial to replace existing esterification methods with more environmentally benign processes.

Various ionic liquids (ILs) have been used as catalysts for preparing biodiesel from long-chain FFAs and can be easily recycled [12-14]. In particular, $\mathrm{SO}_{3} \mathrm{H}$-functionalized ILs have been successfully used as catalysts and reaction media for biodiesel production, resulting in excellent performance and high yields [15-20]. Among these, the dicationic ILs have received significant attention [21] because of their higher stability as compared with their monocationic analogues. Fang et al. [22] used halogen-free dicationic acidic ILs in the synthesis of biodiesel from FFAs and alcohols, while Zhang et al. [23] prepared three dicationic basic ILs for biodiesel production from soybean oil. Aghabarari et al. $[24,25]$ reported the use of acidic ILs based on bentonite as catalysts for the esterification of oleic acid with short-chain alcohols. However, the relatively high

\footnotetext{
* Corresponding author. Tel/Fax: + 86-310-8577750; E-mail: qinsj528@hebeu.edu.cn

\# Corresponding author. Tel/Fax: +86-22-60202926; E-mail: zhaojq@hebut.edu.cn

This work was supported by the Science Foundation of Hebei Province (B2012402001, D2014402046), Program for One Hundred Innovative Talents in Universities of Hebei Province (BR2-204), and the Science and Technology Foundation of Universities of Hebei Province (Q2012030). DOI: 10.1016/S1872-2067(15)60852-X | http://www.sciencedirect.com/science/journal/18722067 | Chin. J. Catal., Vol. 36, No. 7, July 2015
} 
cost of ILs containing the imidazolium cation hinders their industrial applications. Thus, a more efficient, simple and biodegradable catalyst need to be developed.

In the present work, we prepared quaternary ammonium Brönsted acid surfactant-combined dicationic ILs (BASDILs, Scheme 1) and explored their application as green catalysts for biodiesel production from FFAs and alcohols. To gain an understanding of the acidity-activity relationship, the Hammett method was also employed to evaluate the acidity of the BASDILs.

\section{Experimental}

\subsection{Synthesis of BASDILS}

BASDILs were synthesized according to our previously described protocol [26]. The zwitterionic 1,2-bis[ $N$-methyl- $N$ (3-sulfopropyl)-alkylammonium] ethane betaines ( $\mathrm{CnSbs}$ ) were prepared by the reaction of $N, N^{\prime}$-dimethylethylenediamine with $n$-alkyl bromide, followed by reaction with 1,3-propanesulfonate. Zwitterion acidification was subsequently accomplished by mixing the zwitterions with $p$-toluenesulfonic acid monohydrate.

\subsection{Measuring the acidity of BASDILs}

The Brönsted acidity of the ILs was determined by employing Hammett functions $\left(H_{0}\right)$ together with UV-visible spectroscopy data acquired on a Perkin Elmer Lambda 35 UV-Vis spectrophotometer, following a previously reported procedure $[18,27,28]$. In this process, the BASDIL and the indicator 4-nitroaniline $\left(\mathrm{p} K_{\mathrm{a}}=0.99\right)$ were both dissolved at respective concentrations of 35 and $110 \mu \mathrm{mol} / \mathrm{L}$ in anhydrous ethanol.

\subsection{Esterification reaction}

The esterification reactions were carried out in a $10-\mathrm{ml}$ tube with a reflux condenser. Portions of the catalyst (0.020-0.316 mmol) and of oleic acid (7.9 mmol, $2.23 \mathrm{~g}$ ) were transferred into the reactor and preheated prior to the addition of the alcohol. Upon reaching the desired reaction temperature (25-70 $\left.{ }^{\circ} \mathrm{C}\right)$, methanol $(0.32-1.28 \mathrm{ml})$ was added into the reactor and the reaction was initiated. The reaction mixture was vigorously stirred at a constant rate for all runs. The oleic acid-methanol molar ratio, reaction time and temperature were all varied according to an experimental design. Upon reaction completion, the reactor was cooled to room temperature and phase separation was observed. Excess methanol was evaporated under vacuum and the IL settled to the bottom of the flask because it was immiscible with the ester, which formed the upper layer. Thus, the biodiesel could be separated by simple decantation and the catalyst was easily recycled by removal of water. The conversion of oleic acid was determined by acid-base titration [18].

\section{Results and discussion}

\subsection{Acidity of BASDILs}

The Hammett acidity function $\left(H_{0}\right)$ can effectively express the strength of an acid in an organic solvent, and the $H_{0}$ values of the different BASDILs are summarized in Table 1. These data allow an assessment of the effect of the BASDIL structure on $\mathrm{H}_{0}$. The results demonstrate that the acidity increased with elongation of the hydrocarbon chain (entries 2 and 3) and plateaued when the number of carbon atoms exceeded eight (entries 4, 5 and 9). Moreover, the acidity of BASDILs with different anions decreased in the order $\left[\mathrm{C}_{12} \mathrm{Sb}\right][\mathrm{Tos}]>\left[\mathrm{C}_{12} \mathrm{Sb}\right]\left[\mathrm{HSO}_{4}\right]>$ $\left[\mathrm{C}_{12} \mathrm{Sb}\right]\left[\mathrm{CH}_{3} \mathrm{SO}_{3}\right]>\left[\mathrm{C}_{12} \mathrm{Sb}\right][\mathrm{Br}]$ (entries 5-8), in accordance with the acidity of the anionic counterparts.

\subsection{The catalytic performance for the esterification of oleic acid with methanol}

To simplify the screening process, oleic acid was used as a model substrate, since it is a major and key component of low quality feedstock. The catalytic performance of different

\section{Table 1}

$H_{0}$ values of different BASDILs in ethanol.

\begin{tabular}{lcccc}
\hline Entry & BASDILs & {$[\mathrm{I}](\%)$} & {$[\mathrm{IH}](\%)$} & $H_{0}$ \\
\hline 1 & blank & 100 & 0 & - \\
2 & {$\left[\mathrm{C}_{4} \mathrm{Sb}\right][\mathrm{Tos}]$} & 96.53 & 3.47 & 2.43 \\
3 & {$\left[\mathrm{C}_{8} \mathrm{Sb}\right][\mathrm{Tos}]$} & 77.15 & 22.85 & 1.52 \\
4 & {$\left[\mathrm{C}_{10} \mathrm{Sb}\right][\mathrm{Tos}]$} & 78.03 & 21.97 & 1.54 \\
5 & {$\left[\mathrm{C}_{12} \mathrm{Sb}\right][\mathrm{Tos}]$} & 77.63 & 22.37 & 1.53 \\
6 & {$\left[\mathrm{C}_{12} \mathrm{Sb}\right]\left[\mathrm{HSO}_{4}\right]$} & 82.97 & 17.03 & 1.67 \\
7 & {$\left[\mathrm{C}_{12} \mathrm{Sb}\right]\left[\mathrm{CH}_{3} \mathrm{SO}_{3}\right]$} & 87.64 & 12.37 & 1.84 \\
8 & {$\left[\mathrm{C}_{12} \mathrm{Sb}\right][\mathrm{Br}]$} & 95.06 & 4.93 & 2.28 \\
9 & {$\left[\mathrm{C}_{14} \mathrm{Sb}\right][\mathrm{Tos}]$} & 78.61 & 21.39 & 1.55 \\
\hline
\end{tabular}

Condition for UV-Vis spectra measurements: solvent anhydrous ethanol, indicator 4-nitroaniline at $110 \mu \mathrm{mol} / \mathrm{L}$, BASDIL $35 \mathrm{mmol} / \mathrm{L}, 25^{\circ} \mathrm{C}$.

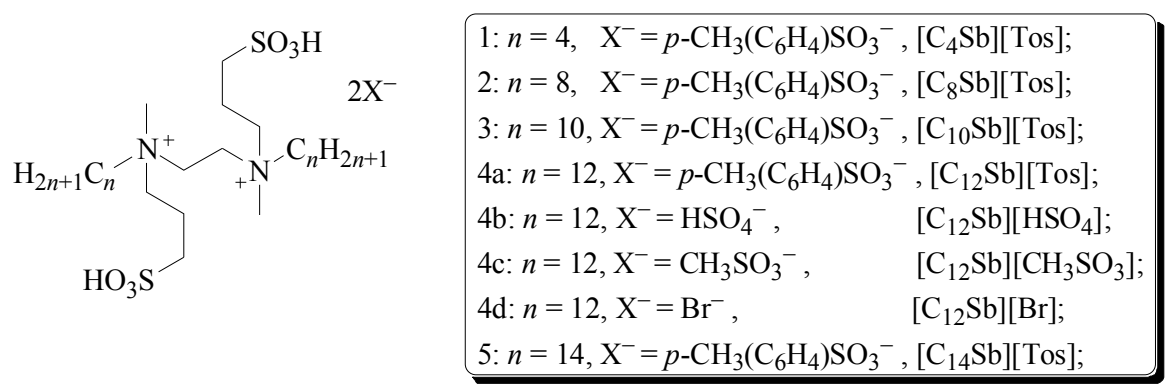




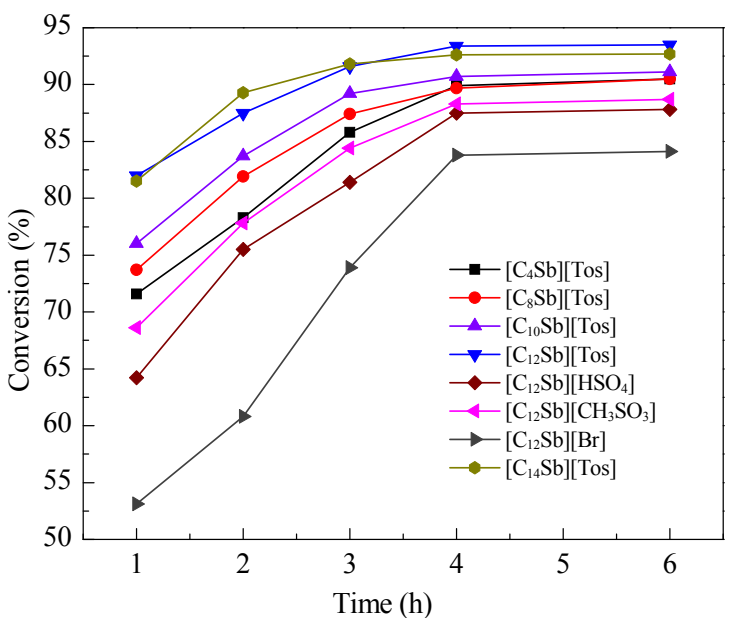

Fig. 1. Conversion of oleic acid versus reaction time using different BASDILs. Reaction conditions: catalyst $2 \mathrm{~mol} \%$, oleic acid $7.9 \mathrm{mmol}$, methanol $15.8 \mathrm{mmol}, 60^{\circ} \mathrm{C}$.

BASDILs is shown in Fig. 1. The catalytic activity of ILs containing Tos $^{-}$associated with different cations followed the order $\left[\mathrm{C}_{4} \mathrm{Sb}\right][\mathrm{Tos}]<\left[\mathrm{C}_{8} \mathrm{Sb}\right][\mathrm{Tos}]<\left[\mathrm{C}_{10} \mathrm{Sb}\right][\mathrm{Tos}]<\left[\mathrm{C}_{12} \mathrm{Sb}\right][\mathrm{Tos}] \approx$ $\left[\mathrm{C}_{14} \mathrm{Sb}\right][\mathrm{Tos}]$. These results suggest that acidity is not the sole factor influencing the efficiency of the catalytic process. $\left[\mathrm{C}_{12} \mathrm{Sb}\right][\mathrm{Tos}]$ was found to dissolve well in methanol to form a homogeneous mixture, thereby accelerating the reaction (Fig. 2 , (a)). We also observed that, upon reaction completion, the time required to achieve phase separation increased with elongation of the hydrocarbon chain. The activities of ILs with different anions were examined and were found to decrease in the following order: $\left[\mathrm{C}_{12} \mathrm{Sb}\right][\mathrm{Tos}]>\left[\mathrm{C}_{12} \mathrm{Sb}_{0}\right]\left[\mathrm{CH}_{3} \mathrm{SO}_{3}\right]>$ $\left[\mathrm{C}_{12} \mathrm{Sb}\right]\left[\mathrm{HSO}_{4}\right]>\left[\mathrm{C}_{12} \mathrm{Sb}\right][\mathrm{Br}]$. This finding was attributed to the enhanced contact between the reactant and the catalyst resulting from the bulky Tos- anion in the IL, suggesting that the presence of a sufficiently acidic proton on the anionic component of the IL played an important role in activating the reaction. Thus, balancing the requirements for a fast reaction rate with low catalyst costs, [ $\left.\mathrm{C}_{12} \mathrm{Sb}\right][\mathrm{Tos}]$ proved to be the most efficient catalyst. As shown in Fig. 1, the conversion increased until equilibrium was achieved after $4 \mathrm{~h}$, and no significant improvements were obtained by further prolonging the reaction time.
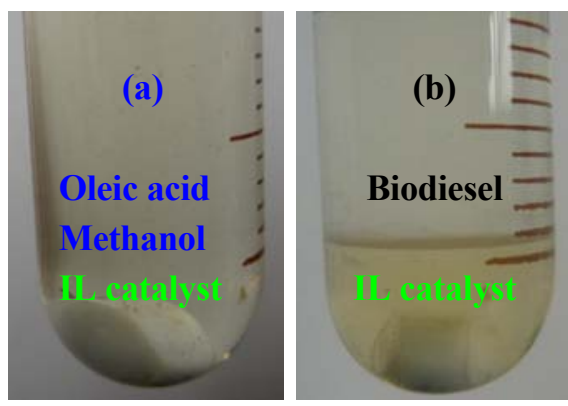

Fig. 2. Photographs of the esterification of oleic acid and methanol catalyzed by $\left[\mathrm{C}_{12} \mathrm{Sb}\right][\mathrm{Tos}]$. (a) The full catalytic system in the tube during the reaction; (b) Phase separation after the reaction.

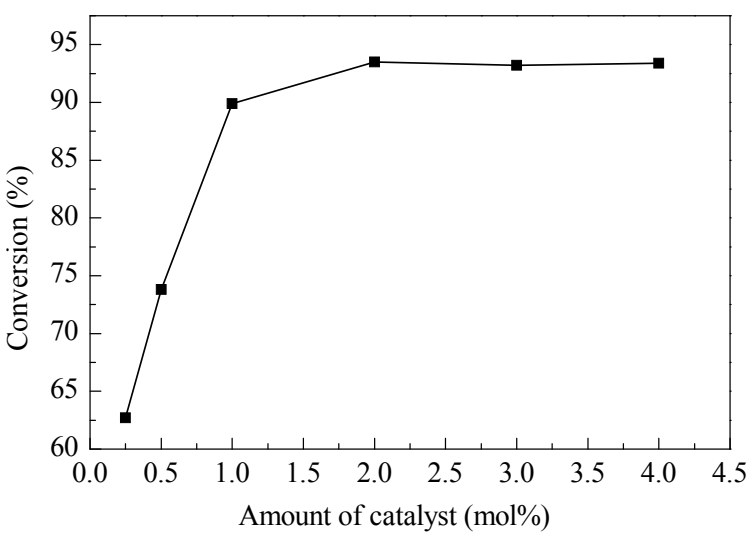

Fig. 3. Effect of the amount of $\left[\mathrm{C}_{12} \mathrm{Sb}\right][\mathrm{T}$ os] on oleic acid conversion. Reaction conditions: oleic acid $7.9 \mathrm{mmol}$, methanol $15.8 \mathrm{mmol}, 4 \mathrm{~h}, 60$ ${ }^{\circ} \mathrm{C}$.

\subsection{Effect of the catalyst amount on the esterification reaction}

The amount of catalyst is an important factor in esterification efficiency. When using a low catalyst loading, the number of available active sites was insufficient to promote the reaction (Fig. 3). Increasing the amount of catalyst from 0.25 to $4 \mathrm{~mol} \%$ resulted in a higher conversion of oleic acid, with the maximum yield of $93.5 \%$ occurring with a catalyst loading of $2 \mathrm{~mol} \%$. Further increasing the catalyst amount did not substantially improve the conversion. Therefore, a sufficient number of active sites were available for the reaction to occur when the catalyst loading was $2 \mathrm{~mol} \%$.

\subsection{Effect of temperature on esterification reaction}

Temperature is another important variable affecting the rate of acid-catalyzed esterification reactions and its effect was examined by performing experiments in the range of $25-70{ }^{\circ} \mathrm{C}$. The results are summarized in Fig. 4. As expected, because of the increase in the equilibrium constant, the conversion of oleic acid increased with temperature, reaching a maximum at $60^{\circ} \mathrm{C}$. Further increases in the temperature resulted in reduced conversion because of methanol evaporation. The observed in-

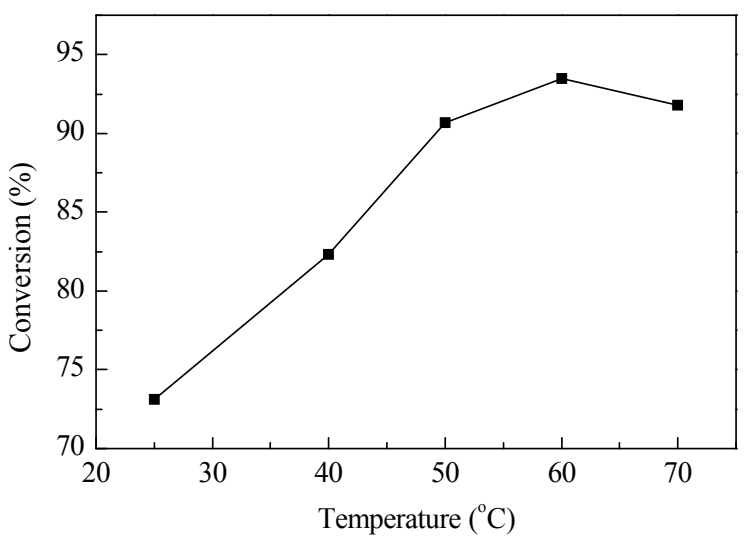

Fig. 4. Effect of the reaction temperature on the esterification. Reaction conditions: oleic acid $7.9 \mathrm{mmol}$, methanol $15.8 \mathrm{mmol},\left[\mathrm{C}_{12} \mathrm{Sb}\right][\mathrm{Tos}] 2$ mol\%, $4 \mathrm{~h}$. 
crease in the conversion with temperature resulted both from the effect of temperature on the reaction rate and also from the significant improvement in the mass transfer between the reactant and the catalyst. Thus, the optimal esterification temperature was $60^{\circ} \mathrm{C}$.

\subsection{Effect of the amount of methanol on the esterification reaction}

An excess of methanol contributed to the esterification of oleic acid by improving the reaction rate. Various methanol/oleic acid ratios between 1:1 and 4:1 were tested, and the results are summarized in Table 2 . The highest conversion of oleic acid (93.5\%) after $4 \mathrm{~h}$ was achieved with a molar ratio of 1.5:1. Further increases in the molar ratio did not result in improved conversion, probably because excess methanol overly diluted the reaction mixture and hampered the workup procedure. Taking into account the energy consumption and the yield, the optimal molar ratio of methanol to oleic acid was 1.5:1.

\subsection{Reusability of [ $\left.\mathrm{C}_{12} \mathrm{Sb}\right][$ Tos] for esterification with methanol}

The recycling performance of [ $\left.\mathrm{C}_{12} \mathrm{Sb}\right][\mathrm{Tos}]$ was investigated by performing several repeat reaction trials under optimum conditions. Upon completion, the reaction mixture was brought to room temperature and two phases were formed (Fig. 2, (b)). The product was isolated from the catalytic system by decantation. The catalyst was then recovered by centrifugation and washed with petroleum ether to remove the organic ester. The results are presented in Fig. 5, showing that there was negligible decline in the catalytic performance after six successive runs. Compared with traditional catalysts, the possibility of efficiently recycling $\left[\mathrm{C}_{12} \mathrm{Sb}\right][\mathrm{Tos}]$ is of interest from environmental and economic perspectives.

\subsection{Results of esterification for different FFAs and alcohols}

To investigate the scope and limitations of [ $\left.\mathrm{C}_{12} \mathrm{Sb}\right][\mathrm{Tos}]$ in terms of the preparation of fatty acid alkyl esters, different FFAs and alcohols were examined (Table 3). Excellent conversion rates were obtained in all cases. Notably, the alkyl chain lengths of both the alcohol and the fatty acid did not have a significant effect on the conversion. Hence, our investigation shows that $\left[\mathrm{C}_{12} \mathrm{Sb}\right][\mathrm{Tos}]$ could be a good candidate for biodiesel production from non-edible oils.

Table 2

Effect of the amount of methanol on esterification.

\begin{tabular}{lc}
\hline Ratio methanol /oleic acid & Conversion (\%) \\
\hline $1: 1$ & 86.1 \\
$1.5: 1$ & 93.5 \\
$2: 1$ & 93.4 \\
$3: 1$ & 92.9 \\
$4: 1$ & 91.2 \\
\hline
\end{tabular}

Reaction conditions: oleic acid $7.9 \mathrm{mmol},\left[\mathrm{C}_{12} \mathrm{Sb}\right][\mathrm{Tos}] 2 \mathrm{~mol} \%, 6{ }^{\circ} \mathrm{C}, 4$ h.

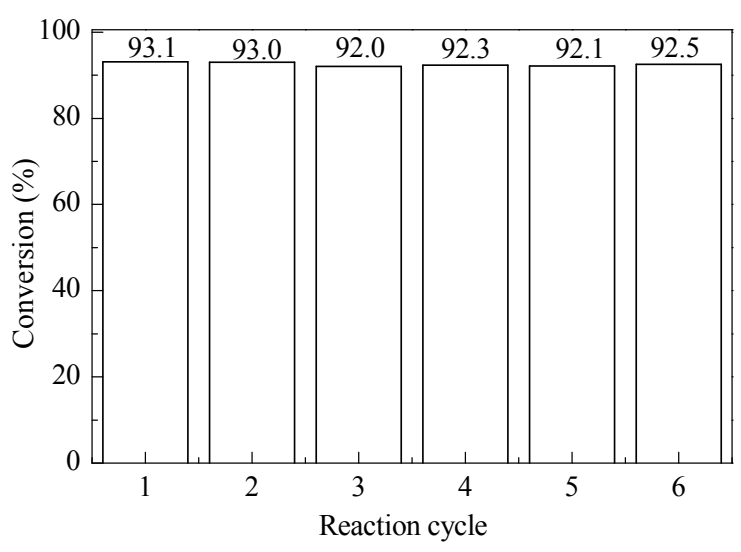

Fig. 5. Reusability of $\left[\mathrm{C}_{12} \mathrm{Sb}\right][\mathrm{Tos}]$ for esterification with methanol.

Table 3

Results for the esterification of different FFAs and alcohols.

\begin{tabular}{lccc}
\hline Fatty acid & Alcohol & Time (h) & Conversion (\%) \\
\hline Oleic acid & Methanol & 4 & 93.5 \\
Oleic acid & Ethanol & 4.5 & 95.7 \\
Oleic acid & Propanol & 6 & 93.3 \\
Lauric acid & Methanol & 3 & 92.7 \\
Palmitic acid & Methanol & 3 & 93.9 \\
Stearic acid & Methanol & 3 & 94.3 \\
\hline
\end{tabular}

Reaction conditions: [ $\left.\mathrm{C}_{12} \mathrm{Sb}\right][\mathrm{T}$ os] $2 \mathrm{~mol} \%$, molar ratio of alcohol:acid $1.5: 1,60^{\circ} \mathrm{C}$.

\section{Conclusions}

Various BASDILs were synthesized and applied as green catalysts for biodiesel production from FFAs and alcohols. The results indicate that the activity of BASDILs is dependent not only on the properties of the anion, but also on those of the cation. [ $\left.\mathrm{C}_{12} \mathrm{Sb}\right][\mathrm{Tos}]$ exhibited the best catalytic activity and biphasic behavior in the esterification reaction. BASDILs containing a long carbon chain were found to efficiently promote esterification because of a 'phase transfer' effect, in which the long carbon chains facilitate mass transfer in the reaction system.

\section{References}

[1] Singh S P, Singh D. Renew Sustain Energy Rev, 2010, 14: 200

[2] Lozano P, Bernal J M, Sánchez-Gómez G, López-López G, Vaultier M. Energy Environ Sci, 2013, 6: 1328

[3] Lee A F, Wilson K. Catal Today, 2015, 242: 3

[4] Qin S J, Sun Y Z, Shi C L, He L Q, Meng Y, Ren X H. Energies, 2012, 5: 2759

[5] Duan X X, Sun G R, Sun Z, Li J X, Wang S T, Wang X H, Li S W, Jiang Z J. Catal Commun, 2013, 42: 125

[6] Wang L T, Dong X Q Jiang H X, Li G M, Zhang M H. Catal Commun, 2014, 56:164

[7] Li Y, Hu S L, Cheng J H, Lou W Y. Chin J Catal (李预, 胡双岗, 程建华, 娄文勇. 催化学报), 2014, 35: 396

[8] Chai M, Tu Q S, Lu M M, Yang Y J. Fuel Process Technol, 2014, 125 : 106

[9] Zhang X H, Su F, Song D Y, An S, Lu B, Guo Y H. Appl Catal B, 2015, 163: 50

[10] Lotero E, Liu Y J, Lopez D E, Suwannakarn K, Bruce D A, Goodwin J 


\title{
Graphical Abstract
}

Chin. J. Catal., 2015, 36: 982-986 doi: 10.1016/S1872-2067(15)60852-X

Brönsted acid surfactant-combined dicationic ionic liquids as green catalysts for biodiesel synthesis from free fatty acids and alcohols

Tao Chang, Leqin He, Xiaojing Zhang, Mingxia Yuan, Shenjun Qin*, Jiquan Zhao*

Hebei University of Engineering; Hebei University of Technology

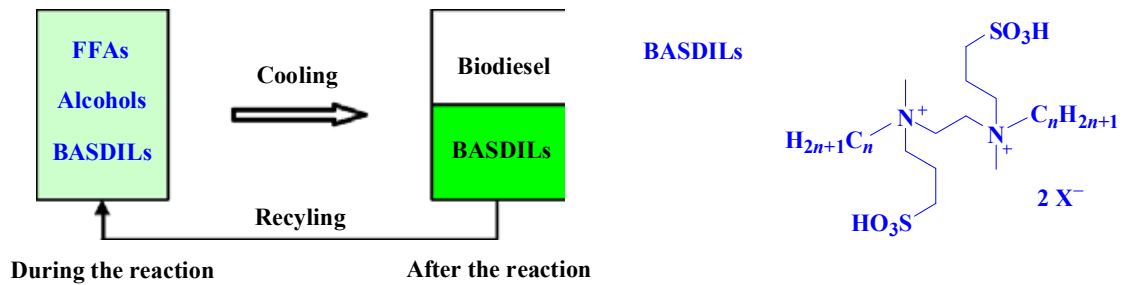

Brönsted acid surfactant-combined dicationic ILs were synthesized and gave high activity for biodiesel synthesis from free fatty acids and alcohols. The structure of ILs influenced the activity.

G, Jr. Ind Eng Chem Res, 2005, 44: 5353

[11] Sani Y M, Daud W M A W, Aziz A R A. Appl Catal A, 2014, 470: 140

[12] Zhang L, Xian M, He Y C, Li L Z, Yang J M, Yu S T, Xu X. Bioresour Technol, 2009, 100: 4368

[13] Fauzi A H M, Amin N A S. Energy Convers Manage, 2013, 76: 818

[14] Fauzi A H M, Amin N A S, Mat R. Appl Energy, 2014, 114: 809

[15] Cole A C, Jensen J L, Ntai I, Tran K L T, Weaver K J, Forbes D C, James H D Jr. J Am Chem Soc, 2002, 124: 5962

[16] Wu Q, Wan H L, Li H S, Song H R, Chu T H. Catal Today, 2013, 200: 74

[17] Wu Z W, Li Z, Wu G M, Wang L L, Lu S Q, Wang L, Wan H, Guan G F. Ind Eng Chem Res, 2014, 53: 3040

[18] He L Q, Qin S J, Chang T, Sun Y Z, Gao X R. Catal Sci Technol, 2013, 3: 1102

[19] Liang X Z. Appl Catal A, 2013, 455: 206

[20] Aghabarari B, Dorostkar N, Martinez-Huerta M V. Fuel Process
Technol, 2014, 118: 296

[21] Anderson J L, Ding R, Ellern A, Armstrong D W. J Am Chem Soc, 2005, 127: 593

[22] Fang D, Yang J M, Jiao C M. ACS Catal, 2011, 1: 42

[23] Fan M M, Yang J, Jiang P P, Zhang P B, Li S S. RSC Adv, 2013, 3: 752

[24] Aghabarari B, Dorostkar N, Ghiaci M, Amini S G, Rahimi E, Martinez-Huerta M V.J Taiwan Inst Chem Eng, 2014, 45: 431

[25] Aghabarari B, Dorostkar N. J Taiwan Inst Chem Eng, 2014, 45: 1468

[26] He L Q, Qin S J, Chang T, Sun Y Z, Zhao J Q. Int J Mol Sci, 2014, 15: 8656

[27] Chang T, He L Q, Bian L, Han H Y, Yuan M X, Gao X R. RSC Adv, 2014, 4: 727

[28] Chang T, Gao X R, Bian L, Fu X Y, Yuan M X, Jing H W. Chin J Catal (常涛, 高晓荵, 边丽, 付西英, 袁明霞, 景欢旺. 催化学报), 2015, 36: 408

\section{双子型Brönsted酸性离子液体催化高级脂肪酸与醇反应合成生物柴油}

\author{
常 涛 ${ }^{\mathrm{a}}$, 何乐芹 ${ }^{\mathrm{a}, \mathrm{b}}$, 张晓婧 ${ }^{\mathrm{a}}$, 袁明霞 ${ }^{\mathrm{a}}$, 秦身钧 ${ }^{\mathrm{a},{ }^{*}}$, 赵继全 ${ }^{\mathrm{b}, \#}$

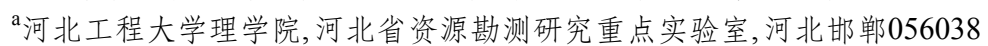

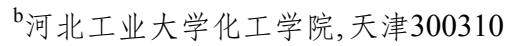

\begin{abstract}
摘要: 合成了一系列双子型酸性离子液体, 该类型离子液体以乙二铵为连接链, 由碳链长度可调的双子型阳离子与不同的阴离子 组成. 因此, 具有相分离催化剂的性质, 并应用于高级脂肪酸与醇的酯化反应, 以合成生物柴油. 详细考察了各参数的影响. 结果 表明, $\left[\mathrm{C}_{12} \mathrm{Sb}\right]\left[p-\mathrm{CH}_{3} \mathrm{C}_{6} \mathrm{H}_{4} \mathrm{SO}_{3}\right]$ 表现出高催化活性及可重复使用性能.

关键词: 生物柴油; 酯化反应; Brönsted酸性; 双子型离子液体; 相分离催化剂

收稿日期: 2015-01-29. 接受日期: 2015-03-27. 出版日期: 2015-07-20.

*通讯联系人. 电话/传真: (0310) 8577750; 电子信箱: qinsj528@hebeu.edu.cn

\#通讯联系人. 电话/传真: (022) 60202926; 电子信箱: zhaojq@hebut.edu.cn

基金来源：河北省自然科学基金(B2012402001，D2014402046); 河北省高校百名优秀创新人才支持计划(BR2-204); 河北省高校 科学技术基金(Q2012030).

本文的英文电子版由Elsevier出版社在ScienceDirect上出版(http://www.sciencedirect.com/science/journal/18722067).
\end{abstract}

